\title{
Research on Fiscal Funding Input of Higher Education in Fujian Province
}

\author{
Qiang Qiu \\ School of Economics and management \\ Minjiang University \\ Fuzhou, China
}

\begin{abstract}
The necessary funding is the basic premise and important guarantee for the development of higher education. As the main source of funding for higher education, the amount of government fiscal input has a great affection on the development of higher education. Based on the study of fiscal funding input in higher education, this paper analyzes the present situation of fiscal funding input of higher education in Fujian province by means of statistical analysis and comparative study. It is found that there are some problems in fiscal funding input of higher education in Fujian, such as insufficient fiscal input, obvious regional differences and low expenditure efficiency. And on this basis, we put forward some corresponding suggestions, such as increasing the fiscal funding input in higher education, allocating the resources in higher education reasonably, and establishing the supervision system of fiscal input in higher education.
\end{abstract}

Keywords-Fiscal funding input; Higher education; Fujian

\section{INTRODUCTION}

Twenty-first Century will be a new era led by information and knowledge economy. An unprecedented revolution in information technology is sweeping the globe with great momentum and changing all aspects of human society. Different from the main resources of material and energy in the first, second industrial revolution, information is the important resource in the society which is dominated by information and the development and use of information resources to develop information economy has become the main content of national economic activities. Only if we understand the production, distribution and use of information knowledge and the use of human capital, we can make a good economic and long-term development in the information society, and the education will lay the foundation for this game ${ }^{[1]}$. At the same time, the higher education with the main task of spreading, preserving and innovating information knowledge is more important in the development of economic activity.
Fujian Province is a major economic belt along the coast and the main body of the construction of the West Side of The Economic Area in Taiwan Straits. Its economic development is more and more important to the entire west coast of the Straits and even to the whole country. In order to better develop the economy, besides having good location advantages and policy conditions, it is important to provide human resources. The main way to provide human resources is education, especially in higher education. The material base that restricts the development of higher education is the scale of education funding [2]. Therefore, through the analysis of the scale and effect of the fiscal input in Higher Education in Fujian Province, this paper compares the gap and deficiency of the fiscal input of higher education in Fujian Province, and puts forward the corresponding policy suggestions, in order to improve the use of fiscal funds for higher education in Fujian.

\section{ANALYSIS ON THE CURRENT SITUATION OF FISCAL INPUT IN HIGHER EDUCATION IN FUJIAN PROVINCE}

\section{A. The changing trend of the Total Fiscal Input of higher Education in Fujian Province}

There are basically three sources of funding for higher education development: fiscal funds, tuition fees and social donation. Table 1 below describes the changes and trends of different sources of funding for higher education in Fujian Province. The fiscal funding input of higher education has risen in different degrees each year. In the 16 years from 2000 to 2015 , the annual increase of fiscal input is $56.50 \%$, and the annual investment amount is more than half of the total amount of higher education funds. And the tuition fee increased from 0.438 billion Yuan in 2000 to 6.51 billion Yuan in 2015 with an annual increase of $86.64 \%$, and the income of social donation increased from 56 million Yuan to 386 million Yuan in 2015 with an annual increase of $36.83 \%$. 
TABLE I.

SOURCE OF HIGHER EDUCATION FUNDS IN FUJIAN PROVINCE (2000-2015 YeAR) (UNIT:BILLION YUAN)

\begin{tabular}{|c|c|c|c|c|}
\hline Year & Total Funds & Fiscal Input & Tuition Fees & Social Donation \\
\hline 2000 & 17.2 & 12.26 & 7.38 & 0.56 \\
\hline 2001 & 23.68 & 15.68 & 9.65 & 0.35 \\
\hline 2002 & 30.62 & 20.96 & 12.01 & 0.47 \\
\hline 2003 & 37.3 & 24.76 & 16.49 & 0.53 \\
\hline 2004 & 46.16 & 29.36 & 19.34 & 0.31 \\
\hline 2005 & 52.45 & 32.72 & 22.29 & 0.39 \\
\hline 2006 & 60.47 & 37.36 & 35.83 & 0.92 \\
\hline 2007 & 78.26 & 41.51 & 41.29 & 0.87 \\
\hline 2008 & 93.71 & 51.55 & 45.04 & 0.77 \\
\hline 2009 & 107.92 & 62.11 & 49.78 & 1.72 \\
\hline 2010 & 120.6 & 69.1 & 51.83 & 2.07 \\
\hline 2011 & 141.3 & 87.4 & 55.73 & 2.57 \\
\hline 2012 & 152.46 & 94.16 & 57.99 & 3.35 \\
\hline 2013 & 163.03 & 102.07 & 61.29 & 3.86 \\
\hline 2014 & 175.95 & 111.31 & 65.1 & 2000 \\
\hline 2015 & 192.04 & 123.08 & & 2007,19 \\
\hline
\end{tabular}

Figure 1 below describes the changing trend of the proportion of fiscal input and tuition fees to GDP in Fujian's higher education. It can be seen from it that the proportion of fiscal input in higher education accounts for a fluctuation between $0.3 \%$ and $0.5 \%$ of GDP, which has not reached the height of $1 \%$ (the proportion of higher education fiscal funds to GDP in the ideal state). In comparison, the proportion of tuition

fees to GDP has been increasing from 2000 to 2007, reaching nearly half of the total amount of higher education funds. Although the proportion of tuition fees to GDP after 2008 has declined, it has exceeded more than half of the proportion of higher education fiscal funds to GDP, or has an increasing trend.

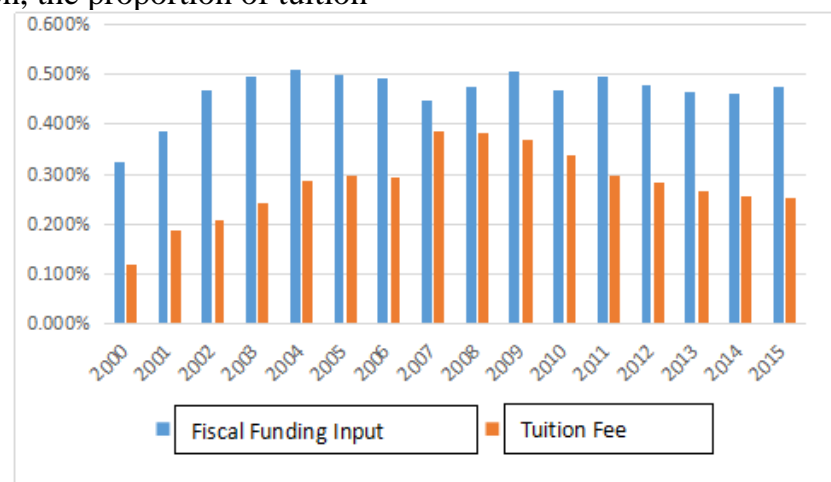

Fig. 1. The proportion fiscal funding input and tuition fees of higher Education to GDP in Fujian Province.

\section{B. Regional comparison of fiscal input in higher education}

For exploring whether the fiscal input of higher education in a country or region is reasonable, not only to see how much the investment is, but to analyze whether it adapts to the level of the local economic development ${ }^{[3]}$. The most commonly used method is to compare the local fiscal input of higher education with other provinces and international levels. In order to make the analysis more specific and scientific, we choose some representative provinces and cities in China to make a comparison: Shanghai whose GDP is close to Fujian; Guangdong whose per capita GDP is close to Fujian; Shanxi and Guangxi whose the education scale (the standard is the number of college students in higher schools) is close to Fujian; Hubei which is in the developed areas of education and Jiangsu which is economically developed. The relevant data of the provinces and cities are shown in Table 2 . It can be seen that the total amount of higher education funds in Fujian is no different from the national average, but there is a big gap between the fiscal input of higher education and the budgetary expenditure on higher education. Compared with Shanghai and Guangdong, the total amount of higher education funds and the fiscal funding input of higher education are far smaller in Fujian. Compared with Shanxi and Guangxi provinces which have the same educational scale, it has some advantages and fiscal input of higher education is higher, but the input level of the two provinces is adapted to the economic development of the province. Compared with the educational developed Hubei province and the economically developed Jiangsu Province, Fujian province is far less than the input of the two provinces, 
whether the total amount of educational funds or the fiscal funding input.

TABLE II. FISCAL INPUT IN HIGHER EDUCATION IN RELEVANT PROVINCES AND CITIES IN 2015

\begin{tabular}{|c|c|c|c|c|c|}
\hline Area & $\begin{array}{c}\text { Total funds } \\
\text { (Billion Yuan) }\end{array}$ & $\begin{array}{c}\text { Fiscal input } \\
\text { (Billion Yuan) }\end{array}$ & $\begin{array}{c}\text { Budgetary funds } \\
\text { (Billion Yuan) }\end{array}$ & $\begin{array}{c}\text { GDP } \\
\text { (Trillion } \\
\text { Yuan) }\end{array}$ & $\begin{array}{c}\text { Per capita GDP } \\
\text { (Thousand Yuan) }\end{array}$ \\
\hline Fujian & 253.12 & 123.08 & 107.58 & 2.59 & 68.3 \\
\hline Shanghai & 744.23 & 362.63 & 327.29 & 2.5 & 103.4 \\
\hline Guangdong & 656.35 & 313.34 & 303.1 & 7.28 & 67.9 \\
\hline Guangxi & 200.01 & 102.2 & 87.09 & 1.68 & 36.5 \\
\hline Shanxi & 201.3 & 111.89 & 94.27 & 1.28 & 35.6 \\
\hline Hubei & 547.18 & 272.09 & 243.59 & 6.3 & 65.8 \\
\hline Jiangsu & 745.21 & 364.92 & 328.97 & 7.01 & 88.5 \\
\hline National average & 257.99 & 169.46 & 154.30 & 2.22 & 49.2 \\
\hline
\end{tabular}

From the international comparison, table 3 describes the fiscal input of higher education in various countries or regions. From this, it can be seen that compared with other countries or

regions, the average proportion of the fiscal funding input of higher education in China is still lower, and Fujian is smaller than the national average level.

TABLE III. FISCAL FUNDING INPUT OF HIGHER EDUCATION IN VARIOUS COUNTRIES OR REGIONS

\begin{tabular}{|c|c|}
\hline National or regional colleges and universities & $\begin{array}{c}\text { The average proportion of the fiscal input to the } \\
\text { education funds }\end{array}$ \\
\hline American public colleges and universities & $57 \%$ \\
\hline National University of Japan & $72 \%$ \\
\hline British universities & $75 \%$ \\
\hline Germany universities & $69.3 \%$ \\
\hline French educational planning colleges and universities & $89.5 \%$ \\
\hline China & $54.3 \%$ \\
\hline Fujian Province & $51.7 \%$ \\
\hline
\end{tabular}

C. Regional comparison of fiscal input in higher education in Fujian Province

There is a big gap in the economic development level of the cities of Fujian province. The economic development of the three cities in Xiamen, Fuzhou and Quanzhou is more prominent, the economic strength is strong and the per capita GDP is higher than the other regions in the province, and especially Xiamen is in the top of the list. Correspondingly, there is a certain gap in the fiscal input of higher education in all cities of Fujian Province, as shown in table 4 below. In three areas of Xiamen, Fuzhou and Quanzhou, the per capita fiscal input of higher education is higher than that of other cities, and only per capita fiscal input of higher education in the three regions is over 15000 Yuan.

TABLE IV. PER CAPITA FISCAL INPUT OF HIGHER EDUCATION IN FUJIAN PROVINCE IN 2015 (UNIT: YUAN)

\begin{tabular}{|c|c|c|}
\hline City & Per capita GDP & Per capita fiscal input \\
\hline Xiamen & 90971.39 & 16104.17 \\
\hline Fuzhou & 75613.73 & 15112.54 \\
\hline Quanzhou & 72722.04 & 15050.42 \\
\hline Sanming & 68249.00 & 13484.85 \\
\hline Longyan & 67121.62 & 13422.46 \\
\hline Putian & 58075.78 & 14876.85 \\
\hline Zhangzhou & 55795.36 & 14732.27 \\
\hline Ningde & 51126.34 & 14077.67 \\
\hline Nanping & 52398.25 & 13193.92 \\
\hline
\end{tabular}

III. PROBLEMS IN THE FISCAL INPUT OF HIGHER EDUCATION IN FUJIAN PROVINCE

\section{A. The total amount of fiscal input in higher education is insufficient}

Although the total amount of fiscal funding input of higher education in Fujian has been continuously improved, the growth rate is still smaller than that of the tuition. The proportion of the fiscal input of higher education to GDP is unstable, which leads to the non-stable trend of fiscal input, and the proportion of the tuition fees to GDP is gradually increasing, thus resulting in the development situation of the government investment is small and personal investment is huge. Meanwhile, compared with other countries or regions, the average proportion of fiscal input in higher education in 
China is still on the low side, and Fujian Province is even smaller than the national average level. Even in the eastern coastal provinces in China, the fiscal input of higher education in Fujian is also significantly lower than that in other provinces. This shows that the Fujian's fiscal funding input of higher education is not enough, and it needs to be promoted in supporting the development of higher education. Therefore, in the steady rising trend of economic strength, the government of Fujian should further increase the fiscal input of higher education, in order to catch up and achieve a balanced development.

\section{B. The obvious regional difference of fiscal funding input in higher education}

The economic development of various regions in Fujian province is not balanced, some areas are relatively fast, and the unbalanced economic development has also led to the imbalance of the fiscal funding input in education. With rapid economic development in the region, the fiscal input of higher education is also greater, which has better promoted the development of higher education. The fiscal input of higher education is relatively small in areas with relatively backward economic development, which restricts the development of higher education, thus leading to the two grade differentiation of the development of higher education. For example, the per capita GDP of three cities in Xiamen, Fuzhou and Quanzhou ranked the top three in the province, gathered more colleges and universities and invested more fiscal funds; the per capita fiscal input of higher education was greater than that of other cities in the province. And the fiscal input was relatively few in other cities with relatively backward economy. This also leads to the slow development of higher education in other cities and behind the three top cities, which also affects the economic development of these regions, and ultimately affects the overall development level and comprehensive competitiveness of Fujian province.

\section{Inefficient use of Fiscal funds in higher Education}

At present, the appropriation mode of higher education adopts the mode of "average plus specialized appropriation" to achieve fiscal appropriation for higher education funds in China. The selection of the form and parameters of the appropriation mode of "average and specialized appropriation" is relatively simple. It is easy to produce the parameter model with the student number as the standard, prompting the university to continuously expand the number of the students, and then expand the scale of the school, increase the input of the hardware and software facilities, and then add a new round of economic burden to the University ${ }^{[4]}$. At the same time, the appropriation model of special projects is to consider the particularity of various colleges and universities. There is no special standard, the subjectivity of the appropriation is strong and the benefit of funds is not high. At the same time, most of the government's allocation of fiscal funds for colleges and universities and the use of funds in Colleges and universities are not open. The degree of transparency has not been fully realized, and it also reflects the weakness of the supervision and evaluation system.

\section{SUGGESTIONS ON OPTIMIZING THE FISCAL INPUT OF HIGHER EDUCATION IN FUJIAN PROVINCE}

In view of the problems and causes of the fiscal input of higher education in Fujian Province, in order to develop economy and education better and realize the win-win situation between economic development and higher education in Fujian Province, this paper combines the concrete situation of Fujian Province, puts forward the following suggestions:

\section{A. Actively increase the fiscal input in higher education and realize the coordinated development of education and economy}

As a major economic zone on the east coast, Fujian province has obvious economic and regional advantages in developing foreign trade and connecting Southeast Asia and Taiwan, and has been supported by a series of national policies. At present, Fujian has six national strategic development plans, including the Pingtan Comprehensive Experimentation Area, China (Fujian) Free Trade Test Area, the core area of the 21stCentury Maritime Silk Road, the Fuzhou New Area, the National Independent Innovation Demonstration Zone and the National Ecological Civilization Test Area, which have injected strong impetus for the economic development of Fujian.

The development of economy is inseparable from the support of excellent talents, and the cultivation of excellent talents comes from a good educational environment. Therefore, in order to promote the better and faster development of Fujian's economy, we must increase fiscal input to education, especially higher education. The fiscal funding investment in higher education needs to follow the pace of regional economic growth. Its growth rate can be properly higher than the speed of economic growth, thus positively promoting the development of local higher education, broadening the scale of higher education, inviting the talents, promoting the transformation ability of scientific research results and the contribution rate to the society, thus achieving more coordinated development of higher and regional economy ${ }^{[5]}$.

\section{B. Realizing the rational allocation of higher Education Resources and eliminating the polarization of Regional Economic Development}

Human capital theory shows that, for economic growth, human capital plays a key role, and human capital investment will increase with economic growth, thus further promoting economic growth. The relationship between the two is mutual support and promotion. There is a similar relationship between the fiscal input of higher education and regional economic growth. If the rational allocation of educational resources cannot be realized, it will lead to the hindered development of higher education, and the development of the economy will also be affected, and the polarization trend will be formed ${ }^{[6]}$. Therefore, in view of the unbalanced economic development in the region, the government should pay more attention to the investment and resources of the economically backward cities in the fiscal funding input of higher education, and allocate more funds to the relatively backward areas, thus they can develop education better, train and retain high-quality talents 
which contribute to regional economic development, improve the level of economic development in various regions, and ultimately achieve the comprehensive competitiveness of Fujian province.

\section{Establishing the Supervision system of Fiscal input of higher Education to improve the efficiency of using funds}

Correct and effective fiscal input is a good catalyst for the development of higher education. In order to achieve correct and effective, we need to evaluate the development of fiscal input in higher education. The first is to establish the evaluation and analysis of the mode of fiscal appropriation. In view of the single problem of the mode and parameter selection of the mode of fiscal appropriation, the third party intermediary evaluation model can be introduced to make a reasonable assessment of the amount of the appropriations for various colleges and universities to realize the fairness of the fiscal appropriation and improve the transparency. Secondly, for the problem of the efficiency of education funds, we can establish the fiscal supervision system, reasonable financial planning, through the analysis of the benefit produced by the higher education from the fiscal input, and more rationally arrange the limited fiscal resources into the more needed higher education development ${ }^{[4]}$, so that the development of the economy will lead to the development of higher education. At the same time, the development of higher education will also push forward economic development and achieve win-win situation.

\section{CONCLUSION}

This paper makes a longitudinal comparison between the fiscal input of higher education and the input level of different years in Fujian in order to explore the changing trend of the fiscal input of higher education in Fujian Province, and then to find the gap of fiscal input of higher education in Fujian by comparing with the different areas in China, and the average level of fiscal input at home and abroad, thus which can clear the direction for local governments to make efforts and put forward feasible suggestions.

Through longitudinal comparison, we can see that during the 2000-2015 years, the fiscal input of higher education in Fujian has increased year by year, which shows that the government's input in higher education has been enhanced. But the proportion of fiscal input of higher education to GDP fluctuates in the range of $0.03 \%-0.05 \%$, although GDP is increasing year by year. Through the horizontal comparison, it is known that in the absolute number of the total fiscal funds of higher education, Fujian is lower than the domestic average. In the total amount of higher education funds, the proportion of the fiscal funding input of higher education in Fujian is far below the national average level, which is far more different from the international level, leading to the excessive burden of the individuals.

In order to change this situation, the government should increase the fiscal input in higher education, and pay more attention to the economically backward cities in the fiscal input of higher education, and optimize the funding mode of higher education, set up a supervision system for fiscal input of higher education, and improve the efficiency of funds use.

\section{REFERENCES}

[1] Pierre Courtioux, Vincent Lignon. "A Good Career or a Good Marriage: The Returns of Higher Education in France", Economic Modelling, vol.57, 2016, pp .221-237.

[2] Li Yongning, "Current situation and suggestions on fiscal policy of higher education ", Research of Finance and Accounting, vol.11, 2006, pp. 12-14.( In Chinese)

[3] Yang Yandong, Zhang Qingjun, "Research on the scale of financial input, demand matching and economic effects of higher education", Studies of Finance and Accounting in Education, vol.3,2014, pp. 3-8

[4] Guo Hua Qiao, "Performance evaluation of educational financial input: a case study of higher education investment", Journal of Zhongnan University of Economics and Law, vol.6, 2011, pp. 101-106.

[5] Zhao Shanqing, "Suggestions for increasing financial input in Higher Education in Jiangsu", Friends of Accounting, vol.9, 2013, pp. 119-123.

[6] Zhou Xiuyang, Research on the financial input of higher education in Jiangxi, Jiangxi University of Finance and Economics, 2012. 